\title{
Short Transient Receptor Potential Channel 4-Associated Protein
}

National Cancer Institute

\section{Source}

National Cancer Institute. Short Transient Receptor Potential Channel 4-Associated

Protein. NCI Thesaurus. Code C131286.

Short transient receptor potential channel 4-associated protein (797 aa, $91 \mathrm{kDa}$ ) is encoded by the human TRPC4AP gene. This protein may play a role in both ion channeldependent transport and protein ubiquitination. 